\title{
Mutualitas Si Tou Timou Tumou Tou: Hospitalitas Kultural Toleransi Komunitas Jawa Muslim dan Minahasa Kristen di Tondano
}

\author{
Mutuality Si Tou Timou Tumou Tou: Tolerance Cultural \\ Hospitality of Muslim Javanese and Christian Minahasa \\ Community in Tondano
}

\author{
Rivo Wakulu* \\ Magister Sosiologi Agama, Fakultas Teologi, Universitas Kristen Satya Wacana, Indonesia \\ Diterima: 18 Juli 2021; Direview: 31 Juli 2021; Disetujui: 19 Agustus 2021 \\ *Coresponding Email: 752018031@student.uksw.edu
}

\begin{abstract}
Abstrak
Tulisan ini menganalisa dan memberikan gambaran secara umum mengenai makna falsafah Si Tou Timou Tumou Tou dalam komunitas Jawa Muslim dan Minahasa Kristen di Tondano. Lebih dalam, penulis mencoba melihat bagaimana Falsafah hidup Si Tou Timou Tumou Tou yang merupakan semboyan orang Minahasa diterapkan dan dihidupi oleh komunitas Jawa Muslim dan Minahasa Kristen di Tondano sebagai perekat serta upaya membangun relasi dengan kehidupan masyarakat yang beragam. Tulisan ini mengambil kesimpulan bahwa untuk mendorong relasi yang penuh damai dan terciptanya pemeliharaan hidup bersama, diperlukan suatu konsep hospitalitas kultural yang melampaui toleransi sesuai dengan konteks permasalahan di daerah masing-masing. Menggunakan perspektif sosiologis tulisan ini mengkaji sejauh mana nilai hospitalitas kultural dapat berperan dalam relasi lintas agama di Tondano. Pada bagian akhir, tulisan ini akan mengeksplorasi konsep kultur orang Tondano yang tertuang dalam falsafah hidup Si Tou Timou Tumou Tou sebagai sebuah upaya melampaui toleransi antarkomunitas agama, sekaligus menjaga eksistensi warisan sejarah kebudayaan lokal.
\end{abstract}

Kata Kunci: Hospitalitas; Mutualitas; Si Tou Timou Tumou Tou; Jawa Muslim; Minahasa Kristen.

\begin{abstract}
This paper will analyze and provide a general description of the philosophical meaning of Si Tou Timou Tumou Tou in the Javanese Muslim and Christian Minahasa communities in Tondano. More deeply, the author tries to see how the philosophy of life of Si Tou Timou Tumou Tou, which is the slogan of the Minahasa people, is applied and lived by the Javanese Muslim and Christian Minahasa communities in Tondano as an glue and an effort to build relationships with the lives of various communities. This paper draws a temporary conclusion that in order to encourage peaceful relations and the creation of the maintenance of shared life, a concept of cultural hospitality that goes beyond tolerance is needed in accordance with the context of the problems in each region. Using a sociological perspective, this paper examines the extent to which cultural hospitality values can play a role in interfaith relations in Tondano. In the final section, this paper will explore the cultural concept of the Tondano people as embodied in the philosophy of life of Si Tou Timou Tumou Tou as an effort to go beyond tolerance between religious communities, while at the same time maintaining the existence of the historical heritage of local culture.
\end{abstract}

Keywords: Hospitality, Mutuality; Si Tou Timou Tumou Tou; Muslim Javanese; Christian Minahasa.

How to Cite: Wakulu, R., (2021). Mutualitas Si Tou Timou Tumou Tou: Hospitalitas Kultural Toleransi Komunitas Jawa Muslim dan Minahasa Kristen di Tondano. Journal of Education, Humaniora and Social Sciences (JEHSS). 4(2): 1175-1185. 


\section{PENDAHULUAN}

Tulisan ini membahas tentang upaya diskursus analitif-deskriptif sebagai kerangka melampaui toleransi dalam konteks Minahasa berbasis falsafah Si Tou Timou Tumou Tou (manusia hidup untuk memanusiakan manusia lain) artinya sampai keturunan hidup ia harus menghidupkan sesama manusia. Kemudian pada tahun 1930-an ketika Pahlawan Nasional Sam Ratulangie aktif dalam segala bentuk kegiatan sosial dan perjuangan melawan bentuk-bentuk ketidakadilan dan ketidaksetaraan, ketika pada saat itu juga dia menjadi ketua perhimpunan mahasiswa Minahasa dan dan banyak lagi tergabung dalam berbagai organisasi. Dimensi Si tou menunjukkan bahwa manusia itu ada, namun keberadaannya itu sekedar menyatakan bahwa dia itu ada. Sekurangkurangnya ada dalam peta dan statstik juga sejarah. Dimensi Si tou timou menunjukkan bahwa adanya manusia itu bukan hanya sekedar berada di suatu tempat, ia juga bertumbuh. Dimensi selanjutnya Si tou timou tumou Tou_menunjukkan bahwa pertumbuhan seorang manusia bukan hanya sekedar bertumbuh, berkembang dan kemudian mati, tetapi pertumbuhan itu mempunyai arah dan tujuan atau adanya kesinambungan yang pasti.

Indonesia merupakan negara yang multikultural dan pluralistik. Hal ini menjadikan Indonesia negara yang kaya akan budaya tetapi di sisi lain juga memiliki potensi konflik yang sangat besar. Indonesia memiliki potensi konflik yang besar tidak hanya karena memiliki beragam ras dan etnis, tetapi juga karena banyaknya perbedaan lain dalam hal kepercayaan dan budaya (Departemen Kebudayaan dan Pariwisata \& UNESCO, 2009). Terdapat beberapa tulisan dan penelitian tentang relasi Islam-Kristen, Lattu dalam tulisannya mengembangkan bahwa sikap terbuka untuk saling belajar dengan agama lain merupakan hal yang baik. Transformasi timbal balik bisa menjadi jalan tengah untuk belajar dan dialog bersama agama lain, transformasi timbalbalik antara Islam dan Kristen sudah lama bereksistensi dari banyak jejak historis pengalamanpengalaman pengembangan intelektual dari intelek Kristen maupun Islam untuk agama masingmasing telah menyentuh sumber-sumber yang sama, yakni dari Yunani klasik. Narasi timbal balik ini menjadi penting sebagai dasar untuk memupuk kebersamaan serta relasi antar agama (Lattu, 2019). Senada dengan Lattu, Ali-Fauzi dan Nurul Agustina menegaskan gerakan binadamai yang pelopori oleh imam dan pastor di Nigeria adalah pilihan yang tepat untuk menghentikan sensitivitas masing-masing agama, mereka memahami bahwa agama bisa membawa perubahan untuk hidup berdampingan serta melihat kembali teks-teks kitab keagamaan yang berbicara cinta dan kasih untuk merekatkan hubungan antar iman dan etnis di Nigeria (Ali-Fauzi, 2017).

Dalam konteks Halmahera relasi Islam dan Kristen juga di kembangkan sebagai pola acuan untuk pembangunan jemaat pasca bias-bias dari konflik yang melanda Maluku Utara waktu lalu, pembangunan jemaat dilakukan untuk memberi ruang kepada warga supaya mempersiapkan diri dalam menerima keperbedaan (Duan, 2018). Beberapa tulisan juga tentang falsafah Minahasa, Liando dalam penelitiannya memfokuskan terhadap penggunaan kearifan budaya lokal Si Tou Timou Tumou Tou sebagai bentuk optimalisasi dalam menjalankan tugas pemerintahan (Liando, 2013). Berbeda yang dikembangkan oleh Pangalila menunjukan bahwa sikap untuk saling mengahargai dan menghormati harus terus dipupuk dan ditingkatkan dalam memelihara kehidupan yang damai, Pangalila melihat kekuatan nilai budaya Si Tou Timou Tumou Tou terhadap peningkatan sikap toleransi dalam kehidupan siswa-siswi di sekolah (Pangalila, 2013). Hal lain juga dikembangkan oleh Sumolang menunjukkan hubungan mendalam antar berbagai macam budaya masyarakat yang terjadi sebagai akibat adaptasi kultural dengan nilai budaya lokal dan falsafah Si Tou Timou Tumou Tou sebagai tameng utama penangkal konflik dan kemungkinan disintegrasi (Sumolang, 2015). Munir Makka dalam tulisannya melihat bahwa Falsafah Si Tou Timou Tuтои Tou sebagai wujud pengertian masyarakat kota Manado dalam menangkal segala bentuk radikalisme (Makka, 2018).

Pokok besar dalam tulisan sebelumnya telah membahas beberapa pendekatan falsafah Minahasa Si Tou Timou Tumou Tou dalam konteksnya sebagai pelengkap khazanah ilmu pengetahuan khususnya dalam topik besar ini. Namun, penelitian sebelumnya belum mengkaji secara mendalam tentang hospitalitas kultural falsafah Si Tou Timou Tumou Tou yang merupakan pola yang turut serta mempengaruhi cara hidup dan berpikir dalam tatanan sosial kemasyarakatan antara Jawa Muslim dan Minahasa Kristen di Tondano, sehingga tercipta 1前 http://mahesainstitute.web.id/ojs2/index.php/jehss @ mahesainstitut@gmail.com 1176

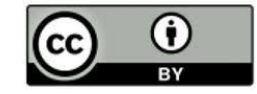

This work is licensed under a Creative Commons Attribution 4.0 
harmonisasi yang luar biasa dengan ragam budaya yang ada. Oleh sebab itu tulisan ini memfokuskan terhadap upaya diskursus analitif-deskriptif mutualitas Si Tou Timou Tumou Tou dalam hospitalitas kultural antara Jawa Muslim dan Minahasa Kristensebagai kerangka melampaui toleransi.

Konteks Minahasa tidak terlepas dari falsafah hidup Si Tou Timou Tumou Tou. Kalimat ini dalam bahasa Indonesia dapat diterjemahkan sebagai manusia hidup untuk menghidupi manusia yang lain, atau dapat disebut manusia apabila telah memanusiakan orang lain. Falsafah ini telah menjadi semboyan hidup orang Minahasa, juga sebagai nafas hidup dalam menjalani kehidupan dan sebagai perekat serta upaya membangun relasi dengan kehidupan masyarakat yang beragam. Manusia itu ada bukan hanya untuk dirinya sendiri, tetapi juga untuk orang lain. Kehidupan heterogen masyarakat Minahasa menjadikan modal sosialsebagai sarana yang prinsipil terhadap tantangan di tengah arus globalisasi.

Dewasa ini isu identitas menjadi sangat vital, hampir dalam setiap pertautan di ruang publik muncul aksi dan aktivitas terselubung yang mengatasnamakan agama, suku dan kepercayaan lain. Berangkat dari hal-hal tersebut timbul klaim-klaim kebenaran dari satu pihak dan pihak lainnya untuk membuktikan mereka yang lebih superior dari lainnya. Bentuk kecurigaan, rasa tidak percaya, ketakutan tidak bisa dihindari lagi dalam kehidupan masyarakat, hal tersebut terus membayangi kehidupan masyarakat Indonesia. Saat ini Indonesia digadang sebagai rumah bersama dalam menjalin sebuah hubungan persaudaraan dan menghargai satu sama lain dengan dasar pancasila bisa dipertanyakan. Karena kebebasan berpendapat dan memeluk kepercayaan serta menikmati praktek ritualnya yang dijamin oleh undang-undang negara, tidak lagi seperti apa yang diharapkan. Seakan negara ini diklaim hanya milik salah satu pihak, sehingga kasus-kasus seperti pelarangan beribadah, pelarangan pembangunan gereja dan masjid oleh beberapa pihak masih banyak terjadi baik di tingkat daerah maupun nasional. Bangsa Indonesia yang mengagungkan paham dan budaya toleransi seakan menjadi bisu dan kaku ketika masalahmasalah dan fenomena intoleransi, tidak ada empati, sukar mengikuti perjanjian, dan kurang peduli terhadap kemanusiaan terjadi serta berkembang sangat cepat (Suryohadiprojo, 2016).

Beberapa kasus seperti konflik antaretnis yang pernah terjadi di Ambon, Poso, dan Sampit ini, menunjukkan bahwa sedikit gesekan dalam perbedaan ini dapat menimbulkan konflik yang luar biasa. Tetapi masyarakat Jaton dan Minahasa mampu membentengi diri terhadap hal seperti itu. Sehingga pertautan antara masyarakat Jaton dan Minahasa di lapangan bukan hanya sebatas ide dan bahasa komunikatif, tetapi melebihi hal tersebut. Harmonisasi aktifitas sosial kemasyarakatan yang berbasis falsafah Minahasa terus dihidupi, sejak Kampung Jaton (Jawa Tondano) berdiri yaitu sekitar Oktober tahun 1830-1831 di bawah pimpinan Kyai Modjo (Djojosuroto, 2012).

Kyai Modjo ditangkap dan dibuang oleh pemerintah Belanda ke Minahasa-Tondano ketika terlibat aktif bersama Pangeran Diponegoro dan pasukannya dalam perang Jawa pada tahun 1825, sampai saat ini tidak pernah ada satu kalipun konflik terjadi antara warga desa beragama Kristen maupun Islam. Walaupun dalam banyak jejak historis dan kultural Pangeran Diponegoro dan Kyai Modjo serta para pengikut-pengikutnya, yang ambil andil besar dalam pecahnya perang Jawa adalah bentuk penolakan terhadap sistem budaya asing, seperti eksploitasi ekonomi, diskriminasi sosial, westrenisasi kebudayaan, dan kristenisasi. Hal ini Nampak juga dalam susunan organisasi pasukan Diponegoro yang berkiblat pada Turki Utsmani (Mansur, 2013). Jadi semua yang bersinggungan dengan budaya asing termasuk di dalamnya adalah agama dan orang yang beragama produk asing harus ditiadakan atau dibumihanguskan (Ulum, 2016).

\section{METODE PENELITIAN}

Metode dalam kajian ini menggunakan studi literatur dengan pendekatan deskriptif kualitatif. Metode ini digunakan dengan mengumpulkan data-data sebagai fakta yang benar melalui sumber-sumber literatur. Lebih lanjut, penulis juga akan menggunakan data pelengkap berupa realitas sosial yang sedang terjadi, baik dari wawancara langsung maupun melalui surat kabar, ataupun diskusi. 
Pertama-tama dipaparkan perspektif kajian teori hospitalitas kultural dan ranah-ranah cakupan yang dimaksud. Hal ini dilakukan untuk memberi gambaran tentang adanya sikap keterbukaan secara absolut terhadap kedatangan yang lain dalam keberlainannya tanpa mendevaluasi, mereduksi, dan menyamakan yang lain. Bagian kedua penulis mencoba memetakan Si Tou Timou Tumou Tou sebagai sebuah imajinasi kolektif bangsa, hal ini dilakukan agar masyarakat Minahasa nantinya dapat tetap ikut terlibat untuk mengkaji dan memahami sejarahnya, dalam rangka menemukan dan membangun nilai-nilai luhur yang terkandung dari setiap peristiwa di masa lampau. Bagian terakhir menguraikan sejumlah perspektif serta menarik benang merah antara teori, analisis data, dan temuan-temuan yang dihasilkan. Setelah melakukan dan menghubungkan langkah-langkah diatas, tulisan ini diharapkan memberi bingkai upaya melampaui toleransi dengan menggunakan dasar pemikiran hospitalitas kultural yang ideal dan dapat di relevansikan dengan konteks permasalahan relasi keagamaan yang sedang dihadapi.

Penelitian ini menggunakan teori hospitality dari Jacques Derrida yang menjelaskan bahwa hospitality atau keramahtamahan adalah sebuah sikap keterbukaan secara absolut terhadap kedatangan yang lain dalam keberlainannya tanpa mendevaluasi, mereduksi, dan menyamakan yang lain (Derrida, 2000). Keterbukaan dalam kesanggrahan/keramahan menjadikan diri subyek selalu dalam risiko dari ancaman yang dapat muncul bersama kedatangan yang lain. Berbeda dari toleransi, hospitality tidak pernah menempatkan yang lain sebagai alter-ego, melainkan sebagai sesuatu yang sepenuhnya lain. Sejauh yang lain dipahami di luar batas-batas konseptualisasi, maka kesanggrahan menuntut kepada setiap orang untuk menjadi tuan rumah (host) yang secara terbuka menyambut kedatangan yang lain, bahkan bila yang lain tersebut menakutkan, atau membahayakan dirinya sekalipun (Derrida, 1999). Selain dari Derrida, dalam penelitian ini akan menggunkanan teori mutuality, ini merupakan salah satu dari empat model pendekatan dalam menyikapi relasi antar identitas yang ditawarkan oleh Paul Knitter. Model mutuality (mutualitas) adalah model dengan menekankan bahwa kasih dan kehadiran Allah ada pada agama-agama lain. Dalam model ini sangat menekankan pada persamaan yang ada di dalam agama-agama sehingga untuk menjembatani persamaan antar agama-agama terdapat tiga jembatan, yakni jembatan filosofis-historis, jembatan religius-mistik dan jembatan etis-praktis. Jembatan filosofis-historis memiliki titik pijak yang mengatakan bahwa tidak ada satu agama pun yang bisa menganggap kebenaran penuh, final dan tidak tersaingi tentang Yang Ilahi karena pengetahuan manusia secara historis terkondisi atau secara sosial terbentuk dan karena itu terbatas (Knitter, 2014).

\section{HASIL DAN PEMBAHASAN}

\section{Falsafah Si Tou Timou Tumou Tou dan Konsep Hospitalitas Kultural}

Dalam kerangka untuk melampaui toleransi, falsafah Si Tou Timou Tumou Tou mengandung makna yang harus dipahami secara mendalam. Tidak hanya sebatas bentuk optimalisasi untuk menjalankan pemerintahan, melainkan lebih dari itu untuk menunjukkan sikap saling menghargai dan menghormati (Pangalila, 2013). Pemahaman akan esensi dari falsafah ini sebenarnya tidak berhenti pada tatanan relasi sosial, tetapi juga didukung relasi emosional dengan adanya kekuatan untuk meningkatkan pemeliharaan kehidupan yang damai.Hospitalitas bahkan lebih daripada suatu keadaan pikiran yang dibaharui dan diwujudkan demi kebaikan pihak tertentu, dan merupakan suatu cara khusus memandang dunia baru. Dalam upaya untuk mencapai hospitalitas, Titaley merefleksikan bahwa keadaan hospitalitas terjadi dalam agama sipil, yakni ketika adanya kesetiaan masyarakat untuk membuat suatu kesepakatan dalam mencapai kehendak bersama, yaitu keadilan dan kesejahteraan sebagai suatu entitas yang sama sebagai manusia (Titaley, 2013). Cara ini mengandung nilai transendental, dimana masyarakat memiliki kesadaran untuk sepakat mewujudkan kesejahteraan bersama secara bersama. Latif menambahkan bahwa hospitalitas inilah yang membuat manusia memperjuangkan konstruksi diri, yang merepresentasikan keberadaan basis demi membentuk identitas kolektif (Latif, 2012). Hal ini bertujuan untuk mewujudkan tatanan sosial yang harmonis. Ngelow juga berargumen bahwa dalam kerangka agama khususnya dalam pewartaan damai, secara praktik hospitalitas berperan untuk memperbaiki sejarah kekerasan atas nama identitas agama tertentu (Ngelow, 2019). Conway 
memandang bahwa meskipun saat ini realitas masyarakat tidak bisa dilepaskan dari konteks yang beragam, tetapi dibutuhkan ruang untuk berbagi (Conway, 2014).

Dalam kajiannya Derrida menempatkan hospitalitas sebagai sebuah sikap keterbukaan terhadap kedatangan yang lain dalam keberlainannya tanpa mendevaluasi, mereduksi, dan menyamakan yang lain. Selain itu, hospitalitas juga membuktikan bahwa manusia diciptakan dengan penuh kasih dan kemesraan dari yang Ilahi, sehingga memunculkan tindakan kerendahan hati. Penerimaan terhadap yang lain bukan juga diawali dengan pertanyaan, tetapi dengan tawaran memberi tempat untuk berlindung. Dalam kesanggrahan/keramahan, baik tuan rumah maupun tamu, dalam ketidakpastian keduanya bisa bertukar posisi, dan identitas masing-masing menjadi rapuh, saling dibongkar dan dibentuk ulang, saling didefinisikan lagi secara baru, oleh "yang lain" (Derrida, 2000). Upaya untuk mewujudkan konsep ini dilakukan dengan menempatkan yang lain sebagai sepenuhnya lain. Derrida ingin menjelaskan bahwa keramahtamahan yang harusnya diterima oleh setiap orang asing atau yang lain secara tak terbatas atau unconditional hospitality. Tak terbatas secara langsung menegaskan bahwa keramahtamahan adalah tentang membiarkan orang lain memasuki ruang milik tuan rumah (Derrida, 1999).

Hospitalitas menurut Derrida masih menunjukkan struktur dalam aktivitas lapangan, dan belum mengalami penyatuan sebagai suatu entitas. Seharusnya jikalau hospitalitas dipandang sebagai bagian dari penerimaan terhadap yang asing secara tak terbatas atau unconditional hospitality, maka tuan rumah atau pun tamu tidak memiliki kecenderungan terjadi salah paham dikarenakan orang asing/tamu bisa saja ikut memiliki ruang dan sumber daya milik tuan rumah, begitupun tuan rumah punya kecenderungan untuk menjadi master control rumahnya (Derrida, 1999). Meskipun demikian, hal ini tidak berarti bahwa hospitalitas atau keramahtamahan tidak berarti dan tanpa makna, hospitalitas tetap menjadi acuan penting untuk pencapain kualitas hidup manusia dalam membangun kesejahteraan. Memang untuk menikmati dan menjalninya buka hal mudah karena setiap entitas kehidupan khususnya manusia sudah tinggal lama dengan sikap agresif, posesif, defensive dan takut terhadap kepunyaan mereka dengan melihat realitas dunia penuh prasangka orang asing akan melakukan kejahatan terhadap dirinya. Meskipun situasinya demikian, praktek hospitalitas seperti apa yg ditawarkan oleh Derrida harus terus dilatih dalam kehidupan guna menciptakan ruang bebas tanpa rasa curiga dan takut dengan orang asing.

Hospitalitas tidak mengubah orang namun menawarkan mereka suatu ruang di mana perubahan dapat berlangsung, juga bukan membawa sesama ke posisi kita, namun menawarkan kebebasan dan tidak terganggu dengan garis yang memisahkan. Aktualisasi tindakan hospitalitas mencakup agama, politik, gender, etnis, pendidikan, keadaan sosial-ekonomi dan sebagainya, artinya sasaran atau tempat hospitalitas ini pada dasarnya dikaitkan dengan rumah, tempat keagamaan, institusi, wilayah, politk dan sosial-ekonomi. Karena itu hospitalitas bukan hanya sekedar jamuan pribadi di rumah, melainkan suatu cara hidup bersama dalam kehidupan yang mencakup semua dimensi publik.

Sejak dikampanyekan kembali oleh Dr. Sam Ratulangi, falsafah ini menjadi pedoman masyarakat Minahasa dalam menjalani kehidupan, bahkan hampir semua di tanah Nyiur Melambai. Apabila dipahami secara mendalam, setiap kata dari falsafah ini mengandung nilai luhur. Pangalila merumuskan falsafah ini dengan makna bahwa manusia sebagai makhluk hidup yang secara dewasa, mendorong dan ikut bertanggung jawab atas kehidupan sesama manusia tanpa memperhatikan kepentingan diri sendiri (Sondakh, 2003). Konsep ini juga mengandung nilai-nilai dasar Pancasila yaitu nilai-nilai yang anti penjajahan, penindasan, otoriter, kemiskinan, kebodohan, pemecahbelahan, yang menjadikan manusia sekedar sebagai objek atau sebagai mangsa, tetapi sebaliknya menghendaki manusia yang merdeka sebagai subjek yang kehadirannya diperlukan sebagai manusia dan memperlakukan orang lain juga sebagai manusia (Sondakh, 2004). Kehidupan inilah yang juga membuat masyarakat turut mewujudkannya dalam tingkah laku hidup dengan semangat kerja sama. Mulai dari mapalus atau sistem kerja sama dalam bidang pertanian, menerapkan amanat dari keturunan Minahasa yaitu Sitou Peleng Masuat (semua manusia sama derajatnya), Maleo-leosan (saling berlaku baik), Masigi-sigian (saling menghormati), Mesawang-sawangan (saling membantu/menopang), Maupus-upusan (saling 
menyayangi/mengasihi) Maesa-esaan (saling menyatu/bersatu) (Karundeng, 2007), dan melayani sesama lewat peristiwa duka membawa bahan ataupun barang yang diperlukan untuk memenuhi kebutuhan (Karundeng, 2010).

Falsafah Si Tou Timou Tumou Tou adalah sebuah hospitalitas kultural masyarakat Minahasa yang tidak memiliki pembedaan antara tamu dan tuan rumah. Semua menjadi sama atau setara dalam aktifitas masyarakat dan tidak ada lagi struktur yang bermain. Melalui konsep inilah manusia memiliki peran besar untuk memanusiakan manusia atau sesamanya, meskipun orang lain dari luar Minahasa. Berkaca dari relasi yang terjadi di antara komunitas Jawa Muslim dan Minahasa Kristen di Tondano, merepresentasikan sikap hidup yang terbuka, saling menerima dan saling memiliki. Baik Jawa Muslim maupun Minahasa Kristen bukan lagi disebut sebagai komunitas yang berbeda, karena keduanya merupakan bagian dari tanah Minahasa yang disebut dengan Kawanua. Istilah ini menunjuk pada adanya kesatuan identitas yang merefleksikan penerapan dari falsafah Si Tou Timou Tumou Tou. Melalui proses hubungan kekerabatan dan interaksi, mereka bukan lagi memandang satu dengan yang lain sebagai yang asing atau yang berbeda, justru semakin menumbuhkan kehidupan yang berdampingan dan rukun. Tanpa melihat rekam jejak konflik yang mungkin pernah terjadi antara komunitas Muslim dan Kristen dalam peristiwa sejarah, konsep ini akan sangat menarik dan relevan dengan realitas global sekarang ini. Selain karena memiliki landasaan budaya dan nilai luhur yang dalam, tetapi ini juga penting untuk diterapkan dalam konteks masyarakat yang telah hidup lama dengan konflik atas nama agama. Bukan hanya sebagai media perdamaian, lebih dari itu akan memberikan kesadaran tentang kesejahteraan bersama yang harus diwujudkan bersama.

\section{Si Tou Timou Tumou Tou sebagai Collective Imjination Bangsa}

Pada dasarnya sejarah memberikan makna yang penting bagi relasi antar umat manusia. Tanpa terkecuali komunitas masyarakat Minahasa pun ikut terlibat untuk mengkaji dan memahami sejarahnya, dalam rangka menemukan dan membangun nilai-nilai luhur yang terkandung dari setiap peristiwa di masa lampau. Seperti halnya dengan peristiwa pertemuan lintas agama antara Kristen dan Islam di Jawa Tondano. Bermula dari kedatangan Kyai Modjo pada 3 Mei 1830, bukan untuk menyebarkan agama Islam tetapi untuk mempertahankan hidup. Peristiwa ini diwarnai dengan perlawanan di Jawa yang menentang kolonialisme Belanda. Sebagai seorang ulama, penasihat spiritual Pangeran Diponegoro, tetapi juga seorang panglima Perang, Kyai Modjo membantu dan mengerahkan para pengikutnya untuk melawan Kolonial Belanda (KDT, 9 Agustus 2019). Tondano yang menjadi tempat tujuan, memberikan kebebasa $\mathrm{n}$ bagi Kyai Modjo dan pengikutnya untuk hidup dan menjalankan agamanya, bahkan boleh kawin dengan orang pribumi dan diberikan empat ringgit perbulannya sebagai tunjangan (WK, 9 Agustus 2019).

Sepanjang perjalanan hidup di Tondano, Kyai Modjo banyak melakukan inovasi baik dalam mengelolah tempat, tetapi juga membangun perkampungan sehingga menjadi aman dan nyaman. Mengelola rawa menjadi persawahan dan menikmati hasil panen serta membagikannya, hal ini membuat hubungan kekerabatan dan interaksi semakin bertumbuh, baik lewat pertanian tetapi juga lewat perkawinan antara orang Minahasa dan Jawa (YK, 5 September 2019). Dalam hal kerjasama ketika sedang menanam padi, orang Minahasa Kristen menghindarkan dan menghalau datangnya binatang seperti babi, sehingga tidak membuat orang Islam terganggu. Begitupun dengan peribadatan atau peristiwa suka/duka, baik Islam maupun Kristen saling membantu membawa makanan dan minuman serta keperluan lainnya menurut tradisi Minahasa yang disebut mawenangan atau me'kan (JA, 19 Agustus 2019).

Relasi yang terjalin di antara komunitas Islam dan Kristen di Tondano ini, bukan lagi sebatas bentuk kepedulian, penghargaan, pengakuan atau kesadaran dalam membangun interaksi dengan yang berbeda. Kedua komunitas ini sudah sampai pada tahap melampaui yang namanya toleransi. Apabila dinilai dari sisi sosial, toleransi mendukung adanya sikap membiarkan, mengakui, dan menghormati keyakinan tanpa adanya persetujuan (Gularnic, 1959). Benyamin Intan dalam bukunya, Public Religion and The Pancasila-Based State of Indonesia mengutip dalam David Little yaitu jawaban suatu kepercayaan yang awalnya tidak diterima, dengan ketidaksetujuan yang disublimasi tanpa menggunakan paksaan (Ahsanul, 2016). Bisa dikatakan bahwa dalam toleransi 11. http://mahesainstitute.web.id/ojs2/index.php/jehss $N$ mahesainstitut@gmail.com 1180 
menuntut adanya perubahan yang menyesuaikan dengan keadaan. Walaupun pada dasarnya tidak mengandung unsur paksaan, dalam beberapa aspek toleransi yang dianut oleh kebanyakan negara plural yaitu toleransi klasik dikenal juga dengan sikap terpaksa membiarkan yang lain hidup karena realitas sosial yang plural. Di sini penguasa/mayoritas membolehkan kolompok-kelompok minoritas hidup sesuai dengan keyakinannya yang bertentangan dengan keyakinan mayoritas sejauh mereka tidak mempermasalahkan otoritas penguasa. Identitas kaum minoritas tetap menjadi hal privat dan hanya boleh eksis dalam ruang yang ditetapkan oleh penguasa. Toleransi adalah hadiah dari penguasa dan setiap saat dapat dicabut jika minoritas melanggar beberapa kesepakatan (Oto, 2016).

Konsep toleransi ini tidak cocok dengan konteks relasi yang terjadi dalam komunitas Jawa Muslim dan Minahasa Kristen di Jawa Tondano. Toleransi masih diperkuat dengan pengaruhpengaruh eksternal seperti adanya penguasa, kelompok mayoritas atau permainan politik. Tidak hanya Indonesia saja yang merasakan dampak dari penyalahgunaan konsep ini, sehingga dampaknya label toleransi seakan menjamin kaum minoritas, padahal pada saat yang sama terus diatur dan dimainkan oleh kaum mayoritas, membuat yang minoritas semakin mudah dimanfaatkan, bahkan direndahkan dan dipersulit.

Kembali pada catatan sejarah pertemuan Muslim dan Kristen, bahwa proses interaksi yang berlangsung tidak mengandung unsur paksaan dari kedua belah pihak. Sejak awal yang ada hanyalah keyakinan dan tujuan murni untuk bisa memberikan kontribusi, baik bagi tempat tujuan dan sebaliknya sebagai tujuan perlu berupaya sebaik mungkin untuk memberikan kenyamanan dan kebebasan terhadap yang datang. Perbedaan keyakinan dan budaya dari masing-masing tidak menjadi ancaman, melainkan sebagai bagian dari realitas yang harus diterima. Hal ini juga berpengaruh dalam tingkah laku hidup yang berdampingan dan rukun yang terus dihidupi bersama, saling menjaga demi menjamin kebaikan dan kedamaian bersama. Bahkan hal yang amat menarik adalah aspek bahasa yang seharusnya dijadikan identitas penanda oleh orang Jawa, berganti menggunakan bahasa daerah Minahasa yang hampir $80 \%$ dipakai dalam kehidupan orang Jawa Tondano. Namun aspek tersebut tidak karena keterpaksaan atau dipaksa, melainkan mengalir begitu saja sehingga menjadi konsensus bersama (MT, 19 Agustus 2019).

Berdasarkan keadaan inilah, perlu adanya lompatan dalam kehidupan sosial yang plural, artinya untuk meninggalkan paham toleransi dan menuju kepada kebijaksanaan yang absolut yaitu hospitalitas atau kesanggrahan. Hospitalitas bukan hanya sekedar menghargai atau menghormati perbedaan. Tidak ada lagi yang namanya minoritas dan mayoritas dalam narasi hospitalitas. Hospitalitas meletakkan nilai maupun cara hidup sosial sebagai bagian yang penting, tanpa ada syarat-syarat atau unconditional hospitality. Berbeda dengan toleransi yang diibaratkan "tinggalkan kami sendiri dan kami akan meninggalkan kamu sendiri", hospitalitas jauh dari pada itu karena menyeberangi suatu batas tanpa menghapusnya, bahkan mendekati dan masuk ke dalam seseorang yang berbeda itu (Febrina, 2018).

Knitter dan Derrida secara jelas dan argumentatif menawarkan konsep untuk melampaui toleransi, bagi Knitter kehidupan mutual dalam relasi antar agama merupakan tindakan yang totalitas sebagai manusia yang religius. Hidup berdampingan dan dialog dengan agama-agama lain merupakan kewajiban etis, sebab hal ini adalah bagian mutlak dari kewajiban mengasihi sesama. Oleh karena itu apa yang dijumpai oleh salah satu agama di dalam tradisi agama lain yang begitu luas, bukan hanya keragaman tetapi mitra dialog yang potensial. Hubungan ini harus mutual, artinya kedua belah pihak harus saling berbicara, mendengarkan dan terbuka untuk belajar dan berubah (Knitter, 2014).

Falsafah Si Tou Timou Tumou Tou sebagai produk khas Minahasa adalah bentuk hospitalitas yang dimaksudkan menjadi lompatan yang melampaui toleransi dalam konteks kehidupan orang Minahasa. Hal ini selaras dengan sikap hidup yang telah diterapkan oleh komunitas Jawa Muslim dan Minahasa Kristen di Tondano, representasi dari pengejawantahan falsafah ini. Belajar dari sejarah permulaan pertemuan antara Muslim dan Kristen tahun 1830, hingga realitas lapangan masa kini yang masih berlangsung. Sikap berdampingan, rukun, saling menerima, saling membangun, satu rasa dan hidup bersama menjadi hasil dari pengaruh semangat islami yang pure 
dan falsafah hidup Minahasa Si Tou Timou Tumou Tou yang nilai-nilainya terus berkolaborasi, berkembang dan berelaborasi dengan lingkungan sekitar, saling memanusiakan atau menolong satu sama lain, tanpa adanya intervensi ataupun reduksi nilai dari pelaku-pelaku kehidupan. Semangat tersebut yang tetap membuat keturunan Kyai Modjo dan etnis-etnis lainnya nyaman tinggal di Minahasa, walaupun tahun 1945 Indonesia telah merdeka dan bisa saja mereka kembali ke daerah asal serta mengelola harta benda mereka. Otomatis mereka memiliki banyak harta benda karena semuanya keturunan-keturunan kerajaan (KDT, 11 September 2019).

Meskipun komunitas Jawa Muslim dan Minahasa Kristen di Tondano hanyalah salah satu dari sekian banyak daerah di Indonesia yang hidup di bawah payung pluralitas, tidak dapat dipungkiri bahwa ancaman dan gesekan akan selalu hadir. Perkembangan ilmu pengetahuan dan teknologi, niscaya akan mempengaruhi tingkah laku bermasyarakat. Tetapi sebagai bagian dari satu kesatuan orang Minahasa, hidup dalam pluralitas sejak lama harusnya membuat masyarakat semakin terbiasa. Perlunya inovasi untuk terus membangun hidup dan memanusiakan orang lain harus selalu dihidupi. Itulah sebabnya falsafah Si Tou Timou Tumou Tou tidak boleh pudar, karena inilah yang menjadi collectice imagination sebagai orang Minahasa. Sebagai collective imagination, falsafah Si Tou Timou Tumou Tou berperan untuk mengumpulkan dan menyatukan tujuan hidup bersama setiap masyarakat Minahasa. Tidak menutup kemungkinan apabila falsafah tersebut menjadi standar atau identitas kultural untuk menjadi bangsa Indonesia. Minahasa adalah Indonesia dalam skala kecil, yang tidak hanya didiami oleh suku Minahasa, tetapi oleh ragam suku dari Nusantara seperti Sunda, Aceh, Padang, Banjarmasin, Palembang, Madura dan banyak lagi dari etnis Jawa. Dapat dikatakan komunitas di Jaton merupakan komunitas campuran yang terpimpin dan benar-benar Indonesia mini dengan menjunjung penuh asas budaya dan falsafah hidup Minahasa (EF, 7 September 2019).

\section{Si Tou Timou Tumou Tou Sebagai Respon Etis Terhadap Tantangan Global}

Berbicara tentang globalisasi tidak hanya berkaitan dengan proyek dan diskursus ekonomi, tetapi mencakup topik kultural yang berdampak terhadap semua aspek kehidupan manusia. Bukan pula hanya soal persaingan ekonomi yang semakin pesat, namun terkait dengan timbulnya kompleksitas dalam relasi antar manusia. Hal ini juga mempengaruhi ruang gerak sosial dan mengaburkan identitas kultural (Ritzer, 2003). Dalam keadaan seperti ini, terjadi pergeseran dari isu kelas sosial masyarakat ke isu identitas kultural. Pergeseran ini kemudian memicu konflik masyarakat global yang tidak hanya menyentuh level lokal, regional, tetapi juga nasional. Hidup dan bertumbuh di tengah perbedaan bukanlah perkara yang asing bagi masyarakat Indonesia. Sebagai masyarakat yang plural, seharusnya dengan kemajemukan yang ada perlu memahami dengan benar bahwa pluralitas terbentuk oleh keutamaan (keunikan) dan kekhasan. Karena itu, pluralitas tidak dapat terwujud atau diadakan atau terbayangkan keberadaannya kecuali sebagai antitesis dan sebagai objek komparatif dari keseragaman dan kesatuan yang merangkum seluruh dimensinya (Muhammad, 2009).

Knitter dalam teori mutualitas yang ditawarkannya memahami bahwa penderitaan global menuntut tanggung jawab global secara bersama, dan hal ini sebagai cikal bakal relasi mutual berproses karena dalam penderitaan tersebut dimungkinkan tumbuh perasaan bersama untuk hidup bersama karena berada dalam satu lingkaran penderitaan secara global (Knitter, 2003). Ia melihat bahwa setiap agama yang berbeda memiliki cara masing-masing dalam memahami kasih dan kehadiran Allah. Dalam dimensi inilah, komponen-komponen yang ditawarkan hampir semuanya bisa menembus segala ruang dalam ranah sosial, realitas dalam ruang sosial pun melihat bahwa ini merupakan suatu bagian penting yang tak bisa ditolak. Namun tidak semudah apa yang dipikirkan ketika menawarkan suatu pilihan atau jalan tengah, karena pada akhirnya Knitter berjalan pada jalur pluralis yang mereduksi keunikan agama-agama lain dengan sedemikian rupa untuk mewujudkan relasi yang baik antar agama.

Seiring berkembangnya zaman, hospitalitas amat dilupakan oleh kalangan masyarakat. Khususnya mereka yang hidup dalam lingkup masyarakat plural yang berkembang dengan beragam konflik atas nama agama. Tantangan demi tantangan kian muncul, mulai dari sikap permusuhan yang dibiasakan, rasa curiga berkembang, prasangka buruk, dendam, dan kemarahan 1] mahesainstitut@gmail.com 
menjadi semacam teror tersendiri dari masyarakat. Apalagi dendam sejarah yang terus dibawa dan dipupuk dari masa lalu. Indonesia adalah contoh negara yang cukup mengekspresikan konflik sosial yang ada di masyarakat, mulai dari aksi politik, pembedaan antara minoritas dan mayoritas, aksi-aksi kekerasasan massa, dikriminasi, intoleransi dan penistaan agama. Perlu diwaspadai jangan sampai bangsa Indonesia yang notabene sebagai negara Pancasila, masih terus menghidupi sikap-sikap primordial.

Manual Castells berpendapat bahwa munculnya aksi perlawanan yang berbasiskan ikatan primordial sebenarnya sebagai upaya resistensi karena kondisi terdevaluasi oleh logika dominasi (Castells, 2004). Keadaan inilah yang akan terus mengancam nilai-nilai kebangsaan, kerukunan dan perdamaian Indonesia. Itulah sebabnya berbagai cara sangat diupayakan demi mencapai stabilitas sosial dan harmoni dalam keberagaman yang ada di tengah gejolak konflik. Menyikapi tantangan ini rasanya menjadi pekerjaan yang cukup berat untuk dihadapi. Selain karena terus memicu retaknya persatuan suatu kelompok atau komunitas, tetapi juga memberi dampak kerugian baik harta benda maupun jiwa akibat dari konflik yang berujung kekerasan. Sedikitnya ada empat hal yang menjadi penyebab konflik masyarakat plural, yaitu perbedaan antara individu karena pertentangan dan perbedaan karakter, perbedaan kebudayaan karena menempatkan ideologi kebudayaan kelompok yang satu lebih unggul dari ideologi kelompok lainnya, perbedaan kepentingan dan kebutuhan manusia yang melekat pada setiap individu/komunitas, dan perbedaan sosial karena pikiran yang konservatif dan integrasi sosial yang sudah ada (Soeroso, 2008).

Konflik bukanlah sesuatu yang dapat dihindari, tetapi harus dihadapi bahkan dicegah. Walaupun konflik selalu dikonotasikan sebagai yang negatif, di sisi lain ternyata konflik memberi pengaruh positif bagi komunitas masyarakat. Hal ini karena konflik dilihat berfungsi sebagai pendorong tumbuh kembangnya suatu kedamaian sosial dan dapat meningkatkan solidaritas (Chandra, 1992). Terlepas dari keuntungan adanya konflik, sudah seharusnya upaya akan penanganan dan pencegahan konflik digaungkan, sebagai bentuk jaminan dan pemeliharaan kehidupan bersama.

Kembali kepada realitas masyarakat plural, komunitas Jawa Muslim dan Minahasa Kristen di Tondano merupakan icon penting bahkan simbol hospitalitas yang perlu ditawarkan bagi kehidupan masyarakat Indonesia. Walaupun di tengah perbedaan, justru hal tersebut tidak dipandang sebagai ancaman, tetapi sebagai ruang yang terbuka untuk saling memelihara keberagaman dan kesatuan yang saling berbaur dan berinteraksi, dengan menghidupi falsafah $S i$ Tou Timou Tumou Tou. Sejalan dengan apa yang dikemukakan oleh Sumolang menunjukkan bahwa hubungan mendalam antar berbagai macam budaya masyarakat yang terjadi akibat adaptasi kultural dengan nilai budaya lokal dan falsafah Si Tou Timou Tumou Tou sebagai tameng penangkal konflik dan kemungkinan diintegrasi (Sumolang, 2015). Bahkan Munir Makka dalam tulisannya melihat bahwa Falsafah Si Tou Timou Tumou Tou sebagai wujud pengertian masyarakat kota Manado dalam menangkal segala bentuk radikalisme (Makka, 2018).

Falsafah Si Tou Timou Tumou Tou merupakan bagian dari kesadaran masyarakat Minahasa untuk mengakui dirinya sebagai orang Minahasa yang paham dan mampu untuk memanusiakan orang lain. Pengakuan ini tidaklah lengkap jika tidak didasari dengan pengenalan yang utuh akan dirinya sendiri, sebelum mencapai pada pengenalan akan orang lain dan perbedaan yang mengikutinya. Dalam tahap penerapannya, kondisi yang seperti ini mengharuskan seorang individu untuk menerima dalam arti, harus bisa berinteraksi dengan individu-individu yang lain, mampu mendorong cara baru yang transformatif untuk saling menerima, saling menghargai bahkan saling mendorong dalam membantu sesama. Perlu digarisbawahi bahwa hal ini terjadi bukan atas dasar keterpaksaan, tetapi karena berlaku kehidupan bersama untuk mencapai tujuan bersama yaitu hidup rukun, penuh kedamaian dan kesejahteraan bersama.

\section{SIMPULAN}


Dalam konteks masyarakat Minahasa, falsafah Si Tou Timou Tumou Tou merupakan hospitalitas kultural yang digunakan sebagai kerangka melampaui toleransi. Berbeda dengan toleransi yang hanya sampai pada titik menghargai dan menghormati orang lain dengan budaya dan keyakinannya, tetapi hospitalitas menunjuk pada bentuk praksis yang bukan hanya terbatas pada dialog, tetapi tindakan penerimaan secara nyata dan mengandung nilai kultural dalam cara hidup dan cara berpikir. Hospitalitas bukan hanya sekedar menghargai atau menghormati perbedaan. Tetapi sampai pada penekanan adanya pengakuan dari kedua belah pihak. Tidak ada lagi yang namanya minoritas dan mayoritas dalam narasi hospitalitas. Hospitalitas meletakkan nilai maupun cara hidup sosial sebagai bagian yang penting, tanpa ada syarat-syarat atau unconditional hospitality. Hospitalitas inilah yang mempengaruhi orang Minahasa dalam falsafah Si Tou Timou Tumou Tou di tengah kehidupan bermasyarakat.

Falsafah Si Tou Timou Tumou Tou merupakan falsafah tua yang mengandung pesan mendalam, dengan semangat jiwa serta nilai-nilai agama dan budaya Minahasa. Falsafah yang bermakna saling menumbuhkan, saling menghidupkan dan saling memanusiakan dalam aktifitas di setiap lapisan kehidupan inilah, yang menjadi konsep hidup bahkan misi sebagai orang Minahasa dalam menjalani hidupnya (Tinggogoy, 2008). Melalui konsep inilah manusia memiliki peran besar untuk memanusiakan manusia atau sesamanya, meskipun orang lain dari luar Minahasa. Hal ini juga menjadi bekal yang dihidupi oleh Komunitas Jawa Muslim dan Minahasa Kristen di Tondano.

Komunitas Jawa Muslim dan Minahasa Kristen di Tondano adalah hasil pertemuan antara Islam dan Kristen tahun 1830, yang dibawa oleh Pangeran Diponegoro dan Kyai Modjo di Tondano. Sejak saat itulah sikap berdampingan, rukun, saling menerima, saling membangun, satu rasa dan hidup bersama terus dipelihara sampai pada masa kini masih berlangsung. Komunitas Jawa Muslim dan Minahasa Kristen di Tondano seakan menjadi icon bahkan simbol hospitalitas yang perlu ditawarkan bagi kehidupan masyarakat Indonesia. Minahasa adalah Indonesia dalam skala kecil, yang tidak hanya didiami oleh suku Minahasa, tetapi oleh beragam suku di dalamnya.

Di tengah tantangan global saat ini, semua cara diupayakan dan dipikirkan untuk menangani dan mencegah terjadinya konflik di Indonesia. Apalagi dengan kenyataan masyarakat Indonesia yang penuh dengan was-was dan kegelisahan terhadap datangnya konflik maupun perasaan akan munculnya teror konflik yang berujung kekerasan. Hospitalitas kultural falsafah Si Tou Timou Tumou Tou adalah salah satu jalan keluar yang perlu ditawarkan kepada masyarakat Indonesia dalam rangka mengupayakan segala bentuk penanganan dan pencegahan konflik yang mungkin muncul. Hal ini juga sebagai cara berpikir dan pola perilaku hidup baru dalam melampaui toleransi. Falsafah ini telah menjadi semboyan hidup orang Minahasa, juga sebagai nafas hidup dalam menjalani kehidupan dan sebagai perekat sosial serta upaya membangun relasi dengan kehidupan masyarakat yang beragam. Manusia itu ada bukan hanya untuk dirinya sendiri, tetapi juga untuk orang lain. Kehidupan heterogen masyarakat Minahasa menjadikan modal sosial sebagai sarana yang prinsipil terhadap tantangan di tengah arus globalisasi. Dalam rangka untuk mencapai hal ini, diperlukan interaksi untuk individu-individu saling menerima dan mampu mendorong cara baru yang transformatif. Dengan semangat dan jiwa yang luhur untuk saling mendorong, saling membangun dan saling menerima dalam perbedaan dengan penuh kepedulian, menyatukan tujuan untuk mencapai keadilan, kesejahteraan, hidup rukun dan damai.

\section{DAFTAR PUSTAKA}

Ali-Fauzi, I.D. (2017). Ketika Agama Bawa Damai, Bukan Perang: Belajar Dari “Imam dan Pastor", Jakarta: Pusat Studi Agama dan Demokrasi (PUSAD) Yayasan Wakaf Paramadina.

Ahsanul, K. (2016). Toleransi Beragama di Daerah Rawan Konflik. Jakarta: Puslitbang Kehidupan Keagamaan. Castells, M. (2004). The Power of Identity. Malden MA: Blackwell Publishing.

Conway, D.T. (2014). Cros-cultural Dialogue on the Virtues, The Contribution of Fethullah Gulen. London: Springer.

Departemen Kebudayaan dan Pariwisata. (2009). bekerjasama dengan Kantor UNESCO Jakarta, Buku Panduan Praktis Pencatatan Warisan Budaya Takbenda Indonesia. Jakarta: Departemen Kebudayaan dan Pariwisata bekerjasama dengan Kantor UNESCO.

Djojosuroto, K. (2012). Dialek dan Identitas Jawa Tondano di Minahasa, Jakarta: jurnal.fkip.uns.ac.id.

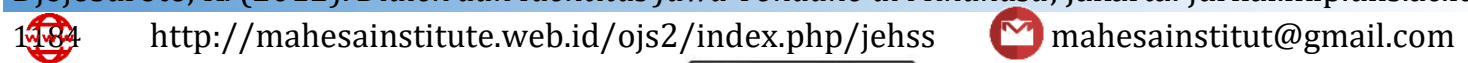


Duan, E.J. (2018). Relasi Islam-Kristen di Halmahera dalam Kerangka Pembangunan Jemaat, Maluku: unhena.ac.id. 2,(2). 55-67.

Derrida, J. (1999). Adieu to Emmanuel Levinas, California: Stanford Univeristy Press.

Derrida, J. (2000). Of Hospitality, California: Stanford Univeristy Press.

Derrida, J. (2001). On Cosmopolitan and Forgivness, London: Routledge.

Febrina, M. (2018). Hospitalitas: Suatu Kebajikan yang Terlupakan di Tengah Maraknya Hostilitas Atas Nama Agama. Jurnal Theologia Aletheia. 6 (1). 57-94 .

Gularnic, G.D. (1959). Webster's Webster World Dictionary of American Languange. New York: The World Publishing Company.

Graffland, N. (1987). Minahasa Masa Lalu dan Masa Kini. Jakarta: Lembaga Perpustakaan Dokumentasi dan Informasi.

Karundeng, R. (2010). Nuwu' Tu'a: Etika Asli Orang Minahasa. dalam Jurnal Exodus No. 2 Tahun XVII.

Karundeng, R. (2007). Tu'ur in Tana: Wale ure, titik pangkal peradaban tou Minahasa dan Goresan Nilai-nilai Kemanusiaan - dalam Waleta Minahasa Edisi IV.

Knitter, F. P. (2003). Satu Bumi Banyak Agama; Dialog Multi-Agama dan Tanggung Jawab Global, terj: Nico A. Likumahuwa. Jakarta: BPK Gunung Mulia.

Knitter, F. P. (2014). Pengantar Teologi Agama-Agama, terj: Nico A. Likumahuwa. Yogyakarta: Kanisius.

Lattu, Y.M.I. (2019). Mutual Transformation in The Early Histories of Christian and Islam. Qudus International Journal of Islamic Studies: 7(1), 1-24.

Latif, Y. (2012). Negara Paripurna: Historisitas, Rasionalitas dan Aktualitas Pancasila. Jakarta: PT Gramedia.

Liando, M.D. (2013). Pendekatan Kearifan Si Tou Timou Tumou Tou Dalam Meningkatkan Kinerja Birokrasi di Sulawesi Utara. Manado: UNSRAT.

Otto, M,G. (2016). Toleransi dan Diskursus Post-Sekularisme. Flores, Jurnal Ladero, 15 (2), 305-322.

Makka, M.M. (2018). Si Tou Timou Tumou Tou Sebagai Wujud Pengertian Masyarakat Kota Manado dalam Menangkal Radikalisme. Manado: IAIN Manado.

Mill, R.C. (1990). Tourism: The International Business. Jakarta: Raja Grafindo Persada.

Muhammad, I. (2009). Islam dan Pluralitas. Jakarta: Gema Insani.

Ngelow, J.N. (2015). Kekerasan dalam Agama: Beberapa Catatan Sejarah dan Teologi Kristen, diakses 25 November 2020, http://www.oaseonline.org/artikel/ngelow-kekerasan.htm.

Pangalila, T. (2013). Pengaruh Internalisasi Nilai Budaya Si Tou Timou Tumou Tou, Mapalus, dan Torang Samua Basudara dalam Pembelajaran PKn Terhadap Peningkatan Sikap Toleransi iswa. Bandung: repository.upi.edu.

Chandra, R. (1992). Konflik Dalam Kehidupan Sehari-hari. Yogyakarta: Kanisius.

Ritzer, G. (2003). Teori Sosial Postmodern. Yogyakarta: Kreasi Wacana.

Suryohadiprojo, S. (2016). Budaya Gotong Royong dan Masa Depan Bangsa. Jakarta: Kompas Media Nusantara.

Soeroso, A. (2008). Sosiologi. Bogor: Quadra.

Sondakh, A. J. (2003). Sitou Timou Tumou Tou, Refleksi atas Evolusi nilai-nilai Manusia. Jakarta: Media Pustaka.

Sondakh, L.W. (2004). Cahaya di Timur Merambah Asia Pasifik. Manado: UNSRAT Press-Media Pustaka.

Sumolang, S. (2015). Torang Samua Basudara: Nilai Budaya dan Kehidupan Antar Umat Beragama di Kota Manado. Manado: Kementrian Pendidikan dan Kebudayaan Republik Indoensia, Sulawesai Utara.

Suryanegara, M.A. (2013). Api Sejarah, Bandung: PT Grafindo Media Pratama.

Tinggogoy, J. (2008). Arti, Nilai, Makna Filosofis: Tumou Tou, Mnejadi Manusia Seutuhnya, Falsafah Hidup Orang Minahasa, Waya Media.

Titaley, A. J. (2013). Religiositas di Alinea Ketiga. Salatiga: Satya Wacana Universitas Press.

Ulum, A. (2016). Kh. Muhammad Shole Darat Al-Samarani, Maha Guru Ulama Nusantara, Yogyakarta: Global Press. 